\title{
14 The Conversion of a Science Institute to a Faculty Library in Ghent, Belgium
}

\begin{abstract}
The Faculteit Letteren en Wijsbegeerte/Faculty of Arts and Philosophy of Universiteit Gent/Ghent University held 50 different library collections, containing 670,000 books, which were scattered over 222 different locations in the city of Ghent. The dispersed collections were a legacy of the former seminar instruction method favoured by many professors in the past and no longer met the needs of academic research and education in the $21^{\text {st }}$ century. A masterplan was developed to bring the collections together. Central to the plan was the renovation of the historic neoclassical building known as the Institut des Sciences/Institute for the Sciences dating from 1892. The project included both the renovation of the building and the amalgamation of all 50 collections under one roof. A primary concern during the renovation process was finding the appropriate balance between the requirements of historic building conservation and the needs of a modern library. After more than ten years of preparation, planning, restoration and relocation, the large new faculty library was opened with much celebration in 2018 . The new library in its historic building, with $13 \mathrm{~km}$ of bookshelves, 8,000 $\mathrm{m}^{2}$ and 1,000 study places, showcases the spirit of the faculty.
\end{abstract}

Keywords: Academic libraries - Belgium; Library buildings - Design and construction; Historic buildings - Remodelling for other use

\section{Introduction}

Ghent University is one of the major universities in Belgium. Established in 1817 by King William I of the Netherlands, it had a faltering start with the 1830 Belgian revolution and two world wars. The original four faculties of the university were Humanities, Law, Medicine and Science which were consecutively taught in Latin, French and Dutch. The democratisation of higher education by means of the 1954 Nationaal Studiefonds/National Study Grant Fund was instrumental in the development of the university into a socially committed and pluralistic institution with more than 44,000 students and 15,000 staff members, 6,000 of whom work at the Universitair Ziekenhuis Gent/ Ghent University Hospital. The university currently ranks $66^{\text {th }}$ in the Academic Ranking of

Ә Open Access. (22021 Paul Buschmann, Anne-Lise Van der Meulen and Raf Van Den Berghe, published by De Gruyter. (cc) BY-NC-ND This work is licensed under the Creative Commons Attribution-NonCommercialNoDerivatives 4.0 International License. https://doi.org/10.1515/9783110679663-015 


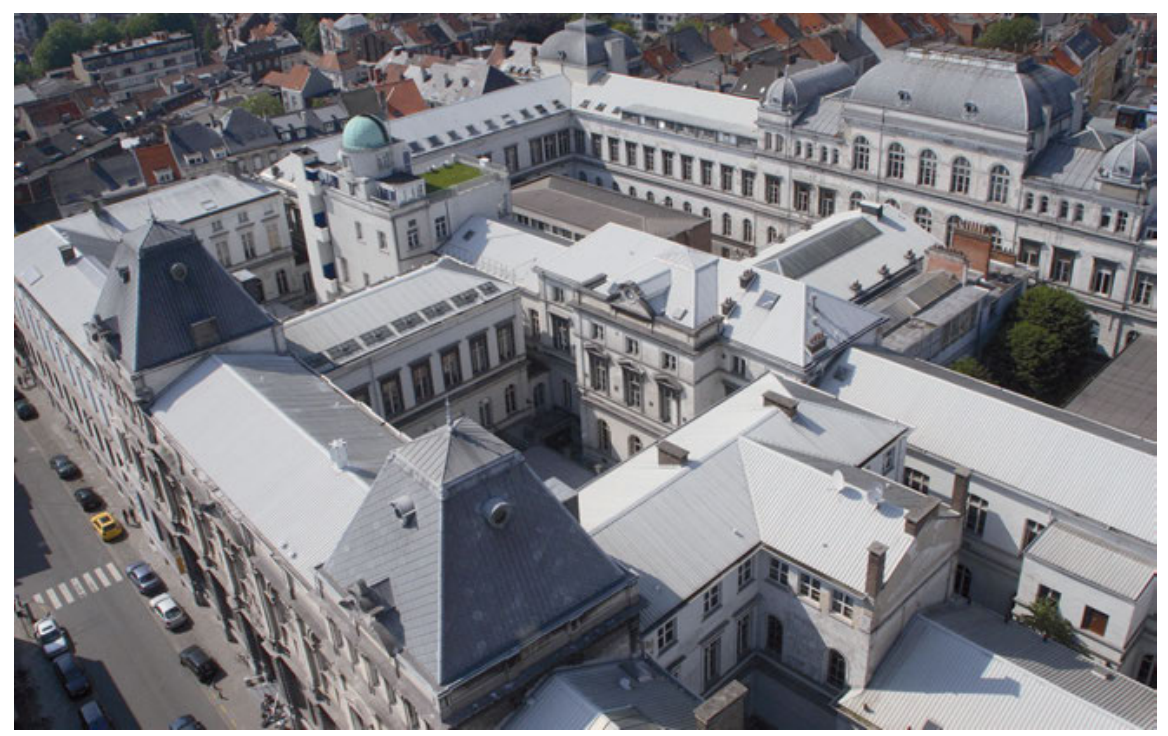

Fig. 1: The Institut des Sciences built in neoclassical style. (c) UGent, Hilde Christiaens.

\section{Facts and Figures}

Name: Faculteitsbibliotheek, Faculteit Letteren en Wijsbegeerte, Universiteit Gent/ Faculty Library, Faculty of Arts and Philosophy, University of Ghent

Address: Rozier 44, 9000 Ghent, Belgium

Website: https://www.ugent.be/lw/nl/diensten/bibliotheek; Faculty library of arts and philosophy (ugent.be)

Opening: September 2018

Architect: 1883: A. Pauli; 2018: Projectbureau UGent (R. Van Den Berghe), Architektenburo Ro Berteloot (part of https://www.arch-teco.com/nl)

Gross floor area: $7,835 \mathrm{~m}^{2}$

Main floor space: $6,953 \mathrm{~m}^{2}$

Collection size: 700,000

Staff: 26

Workstations: 50

Building costs: $€ 8,950,000$

World Universities, also known as the Shanghai Ranking, and takes as its motto "Dare to Think" (https://www.ugent.be/en/ghentuniv/principles/dare-to-think) to encourage a critical approach. In 2017, Ghent University celebrated its $200^{\text {th }}$ birthday and commemorated many eminent alumni such as Nobel Prize winners Corneille Heymans and Maurice Maeterlinck, Internet pioneer Robert Cailliau, 
astronaut Dirk Frimout, virologist Peter Piot and the former Chairman of the International Olympic Committee Jacques Rogge.

The university today hosts eleven faculties and five doctoral schools and offers over 230 academic courses in most scientific disciplines. The Faculty of Arts and Philosophy is one of the main faculties with 5,000 students and offers a wide range of Bachelor and Master programmes within the humanities cluster, including Art, Philosophy, History, Languages and Literature. The Arts Faculty is typically the paper- or book-based faculty in any university and usually associated with a large library collection (Danniau 2017).

The university library comprises a network of nine faculty libraries and two departmental libraries around the Boekentoren/Book Tower (Figure 2) which functions as a central library and repository with closed stacks for research use only. The other libraries have open stacks and everyone including the general public has free access to all libraries within the network. To borrow books, a student, staff or library card is required. The aim of the library network is to facilitate open knowledge creation through four areas of focus: user-driven, web strategy, information literacy and sustainability. The library has a hybrid collection with both print and digital sources of over three million works that are retrievable through an online catalogue.

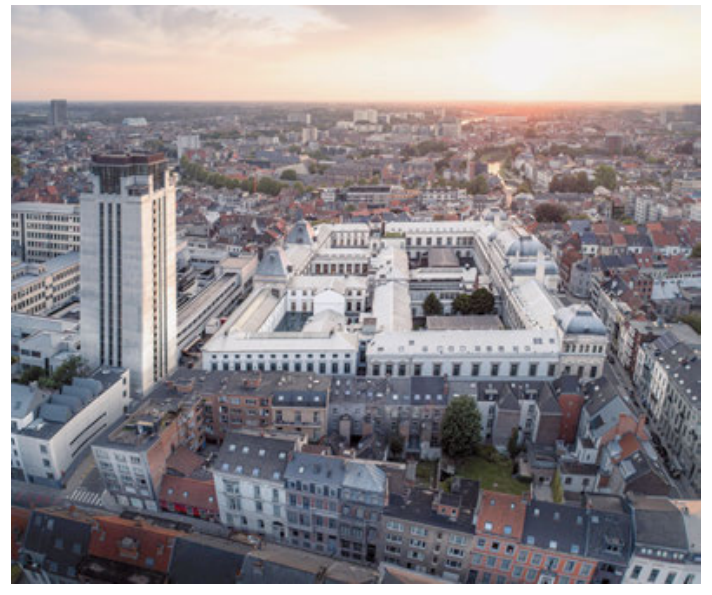

Fig. 2: Campus Boekentoren with University Library and the Institut des Sciences. (C) UGent.

\section{History of the Institut des Sciences}

The Institut des Sciences/Institute for Science was built in the neoclassical style between 1883 and 1890 and designed by the architect Adolphe Pauli. When it opened, it housed the offices for professors and research staff, reading rooms, 
classrooms and laboratories for the science departments which included physics, chemistry, geology and palaeontology, and the technical schools of Ghent University. The design of the building was based on the common layout of the German polytechnic schools at the time with different wings of the building sited around one or more enclosed gardens (Figure 1).

For over a hundred years the building was repeatedly extended and adapted, and the original layout became ever less visible. The enclosed gardens became untidy stone courtyards housing $20^{\text {th }}$ century buildings which blocked the view of the historic façades and contributed to the loss of the original design and ground plan. Up to the 1990s, Ghent University continually altered the building and its interior. Partition walls were erected; corridors were closed; and in several places intermediate floors were constructed in the six-metre-high rooms. By the end of the $20^{\text {th }}$ century, the Institut des Sciences housed many different research groups, departments and spin-offs, and each had its own needs and vision for the use of the building. The Institut des Sciences became a mass of unrelated corridors and rooms. The link with the original design was further eroded due to the use of a wide variety of materials.

In 1994 the complex was designated a historic building worthy of protection because of its artistic, historical, industrial, archaeological and scientific heritage value. Ghent University changed its view of the protected building and it became clear that a thorough renovation was needed. Because of the enormous floor space of over $35,000 \mathrm{~m}^{2}$, the funding required was not immediately available.

The restoration of the building and its use presented Ghent University with many architectural challenges. The size of the building together with its multiple functions meant that the building could not be closed in its entirety for a long period of time. Any restoration had to be phased.

It was not until 2010-2016 that the refurbishment of the exterior walls marked the first step towards the renovation of the building. A key factor was the departure of a major spin-off company occupying a large part of the building which led to discussion about a new future for the building and the beginning of the story of the new Library for the Faculty of Arts and Philosophy. Ghent University was looking for a location for the Library and the renovation of the interior of the southern part of the complex provided the solution. Funding for the renovation of the northern part of the Institut des Sciences was allocated in the university's 2016-2028 investment plan.

The renovation study immediately highlighted that the many alterations and expansions to the building and its interiors had destroyed the clear layout of the original building turning it into a maze in which orientation was extremely difficult. It was decided that the original design could be reconstructed from the $19^{\text {th }}$ 
century plans and the plans for the $20^{\text {th }}$ century expansions, thereby disentangling the multiple architectural knots.

Along with the new Library for the Faculty of Arts and Philosophy, a second library was set up in the northern part of the building, the Faculty Library of Engineering and Architecture. The design work by the internationally renowned Office Kersten Geers and David Van Severen demonstrated that the heritage building still had much to offer particularly when historical context and contemporary architecture combine to produce a successful new use.

\section{History of the Libraries of the Faculty of Arts and Philosophy}

The libraries of the Faculty of Arts and Philosophy of Ghent University have a chequered history described by Defoort and Mantels (2017). At the beginning of this century, there were 50 separate library collections with each serving a particular discipline, research unit or academic programme. The different collections covered diverse subject areas and reflected the varied academic life of the faculty.

The collections were spread over a total of no fewer than 222 different locations in the city of Ghent. Each location had its own opening hours and frequently library regulations resulting in a situation foreign to the expectations of most $21^{\text {st }}$ century students and researchers. Some collections were partly housed in classrooms; others could be found in the offices of professors or research units; and some were in small departmental libraries that could be freely visited. To make things even more complicated, only about half of the collection was catalogued in the university's central library system. With no library management at the faculty level, each of the 50 library collections had its own idiosyncratic classification system. A student who needed a specific book was confronted with an almost impossible task. It was not uncommon for a student of the Faculty of Arts and Philosophy to take a train to Brussels or Leuven to borrow a book from another university's library rather than to try to find it at his or her own institution.

The situation of the libraries at Ghent University was not uncommon and will probably be recognised by colleagues from other older universities. In the $19^{\text {th }}$ century, the humanities adopted a different scholarly approach to its various subject fields. In an analogy with the sciences, researchers created the equivalent of the scientific laboratory: a room equipped with a specialised collection of journals, reference works and textbooks providing a readily available collection. The concept of book laboratories for research in the humanities is a $19^{\text {th }}$ century ideal that got completely out of hand in the $20^{\text {th }}$ century at Ghent with 50 different 
collections at 222 locations, 50 different classification systems, 50\% of the books uncatalogued, no central loan system, demotivated staff and desperate students and researchers. It became clear that it was time to act to bring the faculty's libraries into the $21^{\text {st }}$ century and a masterplan was prepared.

\section{The Masterplan: Heated Debates}

One of the key factors that led to the masterplan was a project to reorganise the entire structure of all the libraries of Ghent University. The plan was conceived and written in 2003 by Lars Björnshauge, the director of the University of Lund (Björnshauge 2003). In the plan, the Book Tower would operate as a closed stack and storage library and focus on the development of the digital library and the overall management of the library organisation. The decentralised units, specifically all the departmental libraries, had to meet minimum criteria to become part of the university library network and subsequently gain access to the services of the Book Tower and central system.

A second factor in drawing up the masterplan was the restructuring of the faculty itself. The number of departments within the faculty was drastically reduced and a reallocation of classrooms and offices followed. The rationalisation of departmental libraries was part of the restructuring.

A third and final factor incorporated in the new masterplan was the decision to completely renovate the Institut des Sciences, which had become vacant as its former science departments moved elsewhere across the city. The empty building provided the ideal opportunity for the relocation of all the separate library collections to one historic building in the centre of Ghent close to the offices of the research units and professors, the auditoria and classrooms of the faculty. It seemed like a perfect fit.

The masterplan was the subject of heated debate in the faculty with supporters of the plan lining up against those who opposed the abolition of the seminar or departmental libraries. The main argument against the proposal was that specialised research collections would no longer be within easy reach. Not surprisingly, professors or research units that had developed their own collections with great care over many years, feared the changes the most. But the advantages of scaling-up were undeniable:

- Lars Björnshauge's report made it clear that faculties with numerous departmental or seminar libraries offered shorter opening hours than a merged facility. The average opening hours of smaller libraries was under 30 hours per week. 
- The Björnshauge report highlighted that the fragmentation of library service led to the payment of hundreds of duplicate journal subscriptions by Ghent University. The financial gain from amalgamation was obvious.

- Many of the smaller departmental or seminar libraries did not meet the minimum standards set by the central university library, making access to the central loan system impossible. As a result, many books went missing.

- Scaling-up and combining available resources would facilitate the provision of new services such as library support for research or education previously unimaginable. If information literacy training existed within the study programmes, it was implemented without the knowledge and experience of the library staff.

One telling anecdote demonstrates the problems associated with the chaotic library set-up and relates to knowing what is in the collection. The chief librarian of the Book Tower received a phone call from a frantic professor. A student who took his class on Ulysses by James Joyce had brought, as requested, a copy of the book to be discussed. The copy of Ulysses was a first edition. The student had found the priceless collector's item in a small open stack departmental library. Better management of the collection was undoubtedly needed.

Eventually, the faculty accepted that the amalgamation of all the 50 library collections would result in a faculty library with longer opening hours, better trained and motivated staff, a rationalisation of the collections and acquisition procedures, the development of a digital library and the introduction of new services that would support education and research at the faculty. It would also enable all the collections to be catalogued and an automated loan system to be provided.

\section{An Academic Centre of Knowledge and Wisdom in the Heart of Ghent}

When selecting a site for the new Faculty Library of Arts and Philosophy, the most important criteria were its size and location in Ghent. The former Institut des Sciences met both requirements. The building not only had enough floor space to house $13 \mathrm{~km}$ of books, but it was also situated beside the faculty's main building. Moreover, the Book Tower is located across the street and holds over $40 \mathrm{~km}$ of books and valuable documents in closed stacks. The storage library, which was built to the design of Henry van de Velde, was undergoing a complete and ongoing restoration during the same period as the new faculty library. The two 
libraries in the same street, one characterised by an imposing neoclassical façade and the other by a modernist tower, would create an academic centre of knowledge and wisdom in the heart of Ghent.

In 2006 the Project Office of the University's Department of Infrastructure and Facility Management was asked to draw up a design for the Faculty Library of Arts and Philosophy. The renovation of the exterior walls, led by the Architektenburo Ro Berteloot, had already commenced.

In the interior (Figure 4) it was important to restore the relationship between all the different corridors and rooms of the building. The renovation process began with dismantling all the walls and mezzanine not part of the original layout. With the removal of the later additions, the large spaces that once contained laboratories and reading rooms, could be restored to their former glory.

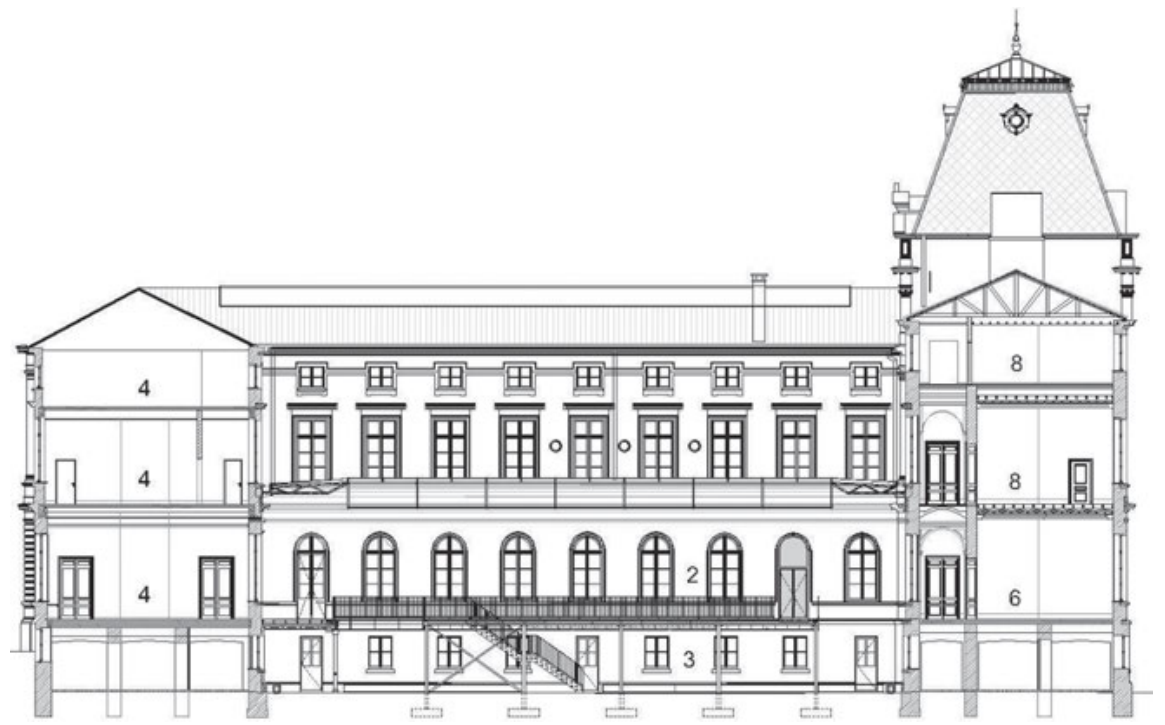

Fig. 3: Section through the atrium with glass roof and floating platform containing the entrance and the reading room. (c) Architektenburo Ro Berteloot.

Some original walls had to be removed to make $3 \times 3 \mathrm{~m}$ openings to combine smaller rooms into larger spaces. The open plan approach provided a good overview of the library. The readability of the whole building was strengthened by the restoration of the original circulation space to facilitate orientation. The three interventions, namely the removal of non-original walls, the creation of new openings and the restoration of circulation, returned the building to a logical and well-organised whole. 


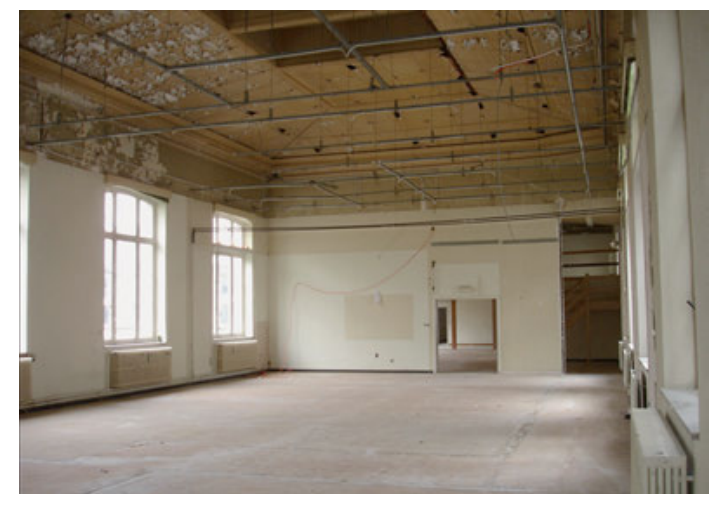

Fig. 4: Situation before the renovation was started. () UGent.

\section{More Than Just Collections of Books and Journals}

When entering the northern part of the building complex, the visitor can take a corridor to the left or to the right. Each leads to one of two wings of the Library, the Loveling wing or the Magnel wing.

The two wings are designed along the same lines. At the entrance is an information desk to welcome visitors. Next to the desk, the user will find workplaces where the library catalogue can be consulted. Print collections are shelved in open access stacks beyond the entrance, a compromise reached to gain agreement to the relocation of collections from the seminar and departmental libraries. The open access stacks allow students and researchers to browse the collections, gain inspiration and make serendipitous discoveries. The decision to operate an open access library meant that shelving takes up a large part of the ground floor. The location of consultation and workspaces had to be carefully considered. Many workspaces were placed throughout the library beside the collections so that the books could be consulted, and the desks used for study purposes. The workspaces are long tables against the walls beneath the windows, optimising the use of natural daylight. The collections are within easy reach of users and, a sense of privacy is afforded to users who have their backs to the shelves (Figure 5).

It goes without saying that a $21^{\text {st }}$ century academic library should be more than a collection of books and journals. New services to address the needs of modern-day students and academics were incorporated in the library. Each wing has its own group workspaces and a library lab where meetings can be held, workshops given, or information sessions delivered. Quiet study space is in high demand and the library provides two silent reading rooms which are heavily used by students. 

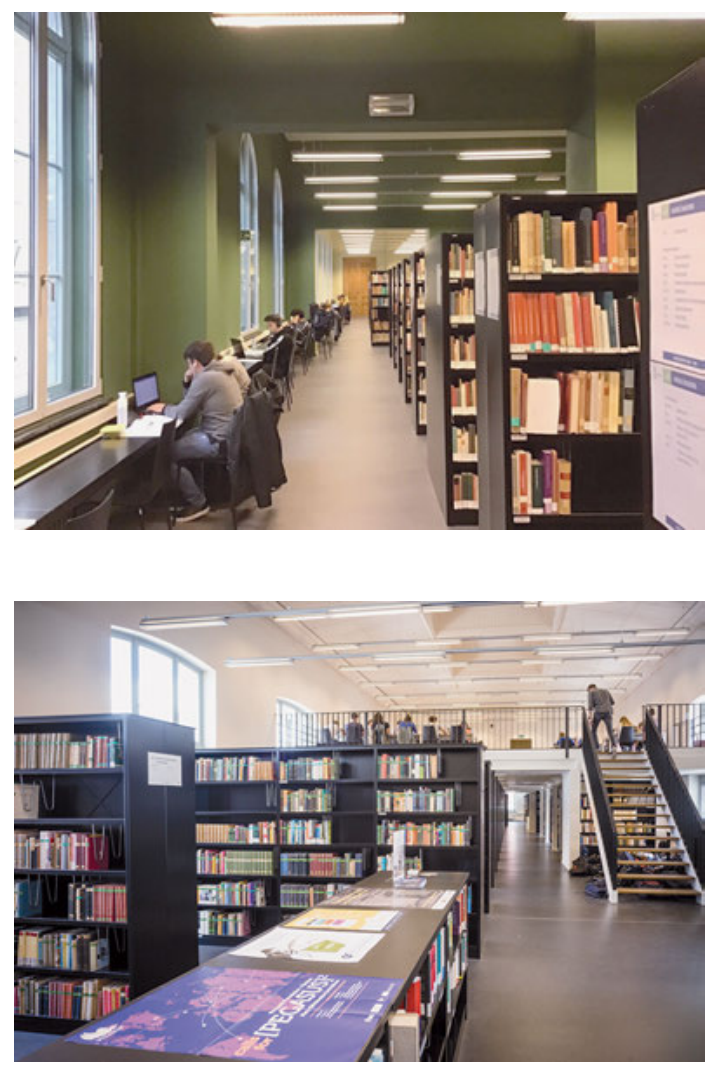

Fig. 5: Workspaces are long tables against the walls beneath the windows. (c) Projectbureau_UGent.

Fig. 6: View of the mezzanine. (c) Christophe Van der Eecken.

A smaller reading room with almost forty desks is located on the first floor of the Magnel wing, which includes a mezzanine (Figure 6). Although the intermediate mezzanine floor is not original, part of it was preserved, but to respect the original historic structure and ensure good lighting, it was set back from the walls. The mezzanine was created to provide additional reader spaces and to offer a good overview of the collections on the first floor.

For the creation of the second reading room, a more drastic architectural intervention was required. The architecture firm Architektenburo Ro Berteloot designed a fully glazed roof above one of the inner courtyards thereby creating an atrium with a floating platform on which the service desk and consultation spaces are located at ground level (Figures 3 and 7). The space underneath the platform on the basement level was turned into a large reading room with over 100 workspaces. The floating platform with its glazed roof enables visitors to reap all the benefits of natural light while studying (Figure 8). 

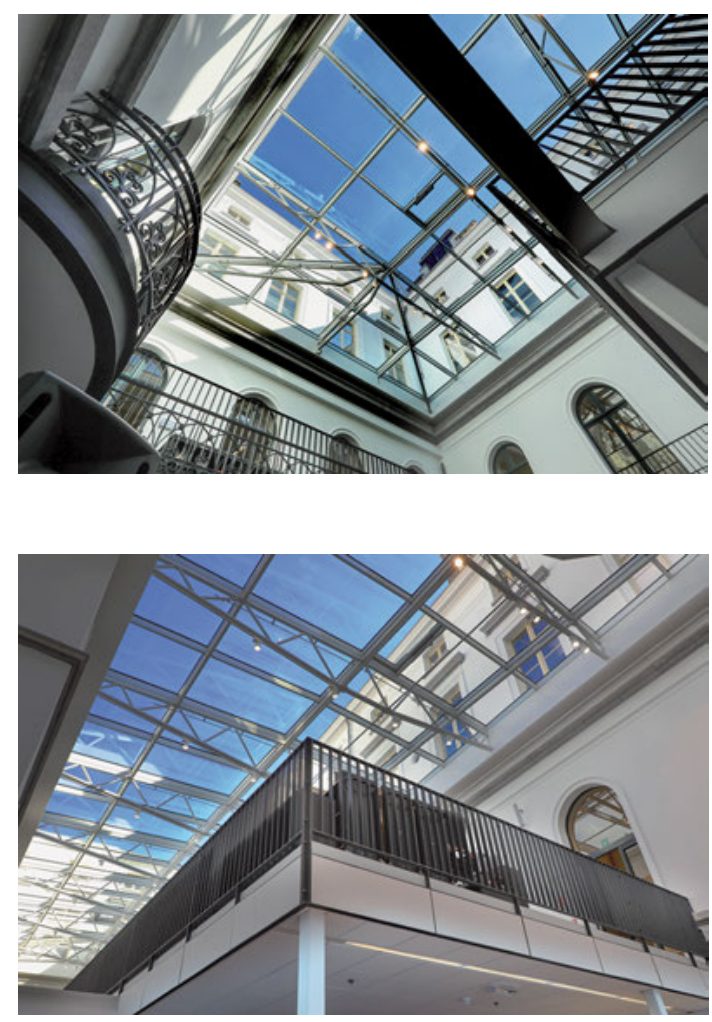

Fig. 7: One of the inner courtyards creating an atrium. (c) Hilde Christiaens.

Fig. 8: The glass roof and the atrium in which a floating platform was placed. (C) Hilde Christiaens.

One of the benefits of locating the large reading room in the former courtyard is that the surrounding rooms and halls can be used to the maximum for stacks holding the book collections. The atrium can be completely closed off from the rest of the library so that this stunning feature of the new library can be easily used as a venue for receptions, exhibitions or talks.

The new library with its two wings has a combined floor space of $8,000 \mathrm{~m}^{2}$, a collection of 13,000 m of books and journals in open stacks, almost 1,000 reading and study spaces, two multimedia rooms or library labs and eight group meeting rooms that can be reserved.

For the interior design, the architects drew heavily on the original interior. Original decorative elements have been conserved and/or restored. The original colour palette was researched and is reflected in the current colour scheme. As is often the case with historic buildings, solutions had to be found to meet requirements concerning accessibility, fire safety and the conservation of the cultural heritage. For example, the wooden floors were fitted with fire-resistant plates without damaging or touching the stucco on the ceilings underneath. A solu- 
tion for the combination of fire-resistant doors with the original wooden doors was also realised. The installation of two elevators, where the architecture of the building allowed, made wheelchair accessibility possible.

Furniture chosen opted for a neutral, simple and plain style. The plain black bookcases and chairs contrast with the neoclassical style of the building and the historic colours of the walls (Figure 9). The arrangement of the shelving bays in continuing rows throughout all the rooms, together with the new openings in the partition walls, ensures that the many different rooms are experienced as a whole and impart a strong sense of uniformity throughout the library. Small but effective interventions turned the vision for the library into reality: a $21^{\text {st }}$ century hybrid library in a $19^{\text {th }}$ century building with print and digital collections and a variety of working, reading and consultation spaces and services. The meticulous restoration of the historical details provides a pleasant and inspiring library atmosphere regaining the magnificence originally conceived by Adolphe Pauli.

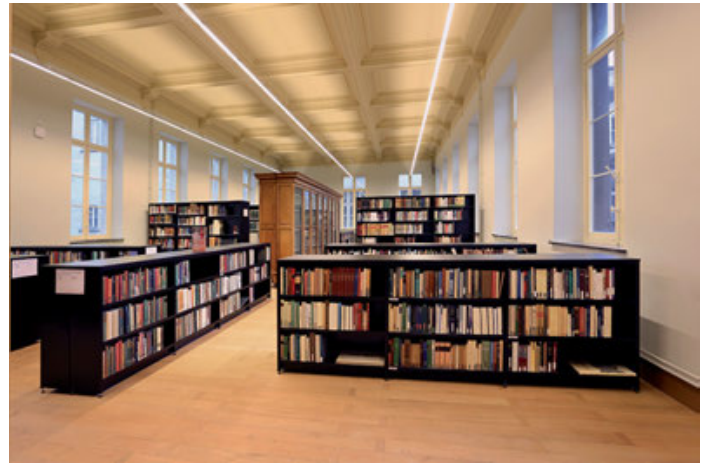

Fig. 9: Plain black bookcases and chairs contrast with the neoclassical style of the building and the historic wall colours. (c) Hilde Christiaens.

The academic library is continually evolving and new functions and services will continue to develop. The future of libraries will no longer revolve around mere print collections. More attention will be given to study spaces and alternative meeting places such as a library lounge, library garden or book café may well be needed. Space will have to be found for these and other new functions. The library staff together with the architects will continue to evaluate the use of space and to reconsider the choices made to ensure that the library remains welcoming to users, adapts to new needs and, ultimately, survives and thrives. 


\section{Library Reorganisation and the Future}

In 2009, a faculty librarian was appointed together with an assistant who was responsible for keeping the library catalogue up to date. They formed the nucleus of the library team at the Faculty of Arts and Philosophy and were not attached to one departmental library. They took an overview of library services and drew up a step-by-step plan with priorities. Working with the architect for the renovation work, the decision was taken to combine all library collections in a three-phase project.

In the first phase in 2012, the first floor of the Magnel wing of the Institut des Sciences was renovated and all the literature collections relocated to it. In the second phase in 2014, the ground, first and second floors of the Loveling wing were renovated for the philosophy, history and art collections. A third and final phase was completed in 2018 when the remaining floors of the Magnel wing were renovated and the linguistics and languages and cultures collections were brought to the new faculty library.

Moving collections is not a simple task. Bringing together all the books and journals from the many different locations was difficult and frustrating work. Often significant parts of a collection surfaced at a later stage and were offered to the library after the collection move to the new location was complete. When all the different parts of a collection were brought together, a retrospective cataloguing project was undertaken. The project involved adding missing catalogue records. Since almost half of the books had no record, over a period of nine years almost 350,000 books were catalogued. Together with the retrospective cataloguing project, the classification systems were rationalised with the added complication that manuals explaining the classification were often missing. And, last but not least, the library team and the academic staff responsible for the collection, had to select $25 \%$ of the items for transfer to storage in the Book Tower.

The intense time pressure and the complexity of moving many different collections, often twice with interim and final locations meant that some activities were postponed. Reclassification was a challenge. Strategically it was important to keep the books in each collection together and to give each collection its own place in the new faculty library to ensure that the bond between a department or research group and its collection would survive the move. Yes, the emotional attachment of users to their books was something that had to be considered when reorganising the library.

After the last 22 collections were moved in the summer of 2018, the faculty library was able to devise a new library policy. One of the overriding emphases in the new policy was the concept of the library as place, as a home for the faculty, as a sacred place (Hahn and Jackson 2008) and as a meeting place. 


\section{Conclusion}

In the beautifully renovated building in the centre of Ghent within walking distance of the offices and classrooms of most of the academic staff, the new library has become the standard bearer of the faculty. To position the library as the real home for faculty life, the new library is proud to host such activities as the annual new year's reception, facilitate exhibitions set up by departments or researchers, and offer a place to host international workshops and readings. The latest initiative which has built a bridge between the library and faculty life is the opening of a Knowmadic Workplace. The library turned a group working space into an office that can be temporarily used by a researcher who needs a quiet and private place to work for a few days or weeks. It is the library's strong belief that although the position of an academic library as the provider of scholarly information is rapidly changing, the library as a sacred place is still one of its strengths. It is the very special position held by the library on a campus that makes the library a so-called heterotopia (Radford, Radford, and Lingel 2015). In a competitive academic world and in a digital environment running at an ever-increasing pace, the library offers a quiet meeting place, a place for reflection and a place for inspiration.

The project is not complete: the renovation of the various courtyards of the building complex and the integration of one courtyard with the library still await. The landmark modernist Book Tower, the university's central library across the street, will also be completely renovated by 2022 . The street that connects both library buildings will become a pedestrian-only zone and serve as a book square where students and locals meet. The street, with its two libraries, one open stack and one closed, in two significant buildings from different architectural periods will tell a unique story of the university. And finally, it is hoped that the auditorium on the first floor that separates the two library wings, can be integrated into the library itself to create a physical connection between the two parts of the library with the additional benefit of creating a much-wanted library lounge and coffee corner.

\section{References}

Björnshauge, Lars. 2003. The Network: The Reorganisation of Library and Information Services at UGent: Full Report. Gent: Universiteit Gent. https://lib.ugent.be/catalog/ rug01:001342960

Danniau, Fien. 2017. “Faculteit Letteren En Wijsbegeerte in Cijfers.” UGentMemorie (Blog), August 18, 2017. https://www.ugentmemorie.be/artikel/faculteit-letteren-wijsbegeerte-incijfers 
Danniau, Fien. “Faculteit Letteren en Wijsbegeerte in cijfers.” UGentMemorie. Laatst gewjzigd 18.08.2017. http://www.ugentmemorie.be/artikel/faculteit-letteren-wijsbegeerte-in-cijfers Defoort, Hendrik, and Ruben Mantels. 2017. "De Lange Weg Naar Björnshauge: De Publieke Diensten van de Gentse Universiteitsbibliotheek, 1960-2017." Archief en bibliotheekwezen in Belgie 88: 75-87. https://biblio.ugent.be/publication/8584988

Hahn, Trudi Bellardo, and Heather Lea Jackson. 2008. "Library as Sacred Place: Applying the Psychology of Religion to the Academic Library as Sanctified Space and Implications for Measurement and Evaluation." Paper presented at World Library and Information Congress: $74^{\text {th }}$ IFLA General Conference and Council, Québec, Canada, August 10-14, August 2008. https://archive.ifla.org/IV/ifla74/papers/091-Hahn_Jackson-en.pdf

Radford, Gary P., Marie L. Radford, and Jessica Lingel. 2015. “The Library as Heterotopia: Michel Foucault and the Experience of Library Space." Journal of Documentation 71, no. 4: 733-51. https://doi.org/10.1108/JD-01-2014-0006 